\title{
5. Scotland and the Politics of Intelligence Accountability
}

Colin Atkinson, Nick Brooke and Brian Harris

This chapter explores the politics of intelligence accountability in the context of the 2014 referendum on Scottish independence and the 2015 General Election in the UK. Drawing upon Peter Gill's model for assessing the effectiveness of security intelligence accountability, it argues that the Scottish Government's proposals for intelligence accountability in an independent Scotland indicated a vague and conservative intention to maintain similar mechanisms to the existing UK political settlement. By exploring the accountability mechanisms for security intelligence in other jurisdictions, this chapter suggests that shortcomings in the Scottish Government's proposals could have been addressed by learning lessons and adopting practices and processes from beyond the UK. The aftermath of the referendum - particularly the landslide victory in Scotland for the pro-independence SNP in the 2015 UK General Election - may herald consequences for both intelligence accountability in the UK and any future plan for accountability mechanisms in an independent Scotland. The previously unconsidered prospect of direct SNP representation on the UK Intelligence and Security Committee (ISC) - now a reality in the UK - raises the scenario that pro-independence politicians will develop the expertise, capital, and political legitimacy necessary for effective intelligence accountability that were lacking in the pre-referendum political landscape. 
In a democratic society, accountability is the requirement for those in positions of power to provide answers to those whom they serve. Accountability depends, therefore, upon either the presence of an informed, inquisitive, and engaged public or an array of elected representatives with similar qualities who act on the public's behalf. Although seemingly straightforward, accountability is not a simple administrative task; it poses a series of profound and fundamentally political challenges concerning the shape, composition, scope, power and limitations of any such regime. These challenges are compounded when one seeks to ensure accountability for the actions of intelligence and security agencies, organisations which, by their very nature, operate in conditions of secrecy. It has been argued that the problem here can be easily stated: 'how to provide for democratic control of a governmental function and institutions which are essential to the survival and flourishing of the state but which must operate to a certain extent in justifiable secrecy'. ${ }^{1}$ Ensuring the democratic accountability of intelligence services has been a persistent problem for western democracies, a challenge compounded by renewed concerns in the post-9/11 era that will undoubtedly persist in the years to come. ${ }^{2}$

In the UK there are various levels of intelligence accountability; however, the parliamentary Intelligence and Security Committee (ISC) is the principal mechanism that exists to provide for the accountability of the nation's intelligence agencies. ${ }^{3}$ Peter Gill has commented upon how the history of the oversight of security intelligence agencies in the UK is short, and how, with one or two exceptions, 'it simply did not exist before the 1970s, though its spread since then has been rapid'. ${ }^{4}$ The ISC was first established by the Intelligence Services Act 1994 to examine

1 I. Leigh, 'The Accountability of Security and Intelligence Agencies', in Handbook of Intelligence Studies, ed. by L. K. Johnson (Abingdon and New York: Routledge, 2007), pp. 67-81 (p. 67).

2 Hans Born and Ian Leigh, 'Democratic Accountability of Intelligence Services', in Armaments, Disarmament and International Security, ed. by Institute Stockholm International Peace Research (Oxford: Oxford University Press, 2007), pp. 193-214.

3 Mark Phythian, 'The British Experience with Intelligence Accountability', Intelligence and National Security, 22, 1 (2007), pp. 75-99; H. Bochel, A. Defty, and J. Kirkpatrick, Watching the Watchers: Parliament and the Intelligence Services (Basingstoke: Palgrave Macmillan, 2014).

4 Peter Gill, 'Evaluating Intelligence Oversight Committees: The UK Intelligence and Security Committee and the "War on Terror"', Intelligence and National Security, 22, 1 (2007), pp. 14-37 (p. 14). 
the policy, administration and expenditure of the Security Service, Secret Intelligence Service (SIS), and the Government Communications Headquarters (GCHQ). The Justice and Security Act 2013 reformed the ISC: making it a Committee of Parliament; providing greater powers; and increasing its remit to include oversight of operational activity and the wider intelligence and security activities of Government. Other than the three main intelligence and security agencies, the ISC examines the intelligence-related work of the Cabinet Office including: the Joint Intelligence Committee (JIC); the Assessments Staff; and the National Security Secretariat. The ISC also provides oversight of Defence Intelligence in the Ministry of Defence and the Office for Security and Counter-Terrorism (OSCT) in the Home Office. Members of the ISC are appointed by Parliament and the Committee reports directly to Parliament. The ISC may also make reports to the Prime Minister on matters which are sensitive in relation to national security. ${ }^{5}$

Intelligence oversight in the UK emerged and developed in the late twentieth and early twenty-first centuries; however, the effectiveness of the UK's accountability mechanisms have come increasingly into question. The responses to terrorist attacks on 9/11, the events that led to the Iraq War and the more recent series of disclosures from both Wikileaks and Edward Snowden revealed a range of controversial programs and activities undertaken by the intelligence agencies that were previously unknown to the public, media, and many politicians. It was against this backdrop - and in advance of the 2014 referendum on Scottish independence - that the Scottish Government decided upon the measures it would propose to ensure the accountability of a prospective security and intelligence agency for an independent Scotland. These measures were subsequently published in the White Paper on Scottish independence titled Scotland's Future: Your Guide to an Independent Scotland. ${ }^{6}$ This chapter evaluates the Scottish Government's proposal for intelligence accountability, locating it in comparative context by understanding the mechanisms that are in place in other

5 The Intelligence and Security Committee of Parliament, 'About the Committee' (2016), http://isc.independent.gov.uk/

6 Scottish Government, Scotland's Future: Your Guide to an Independent Scotland (Edinburgh: Scottish Government, 2013), http://www.gov.scot/resource/0043/0043 9021.pdf. 
similar jurisdictions. It argues that, despite the claim that a range of international comparators were studied, ${ }^{7}$ the Scottish Government's plans sought to replicate the existing UK model, without an appreciation of the challenges of such an approach. It concludes by exploring the political aftermath of the both the 2014 Scottish referendum and the 2015 UK General Election, with a particular focus upon the consequences of this new political landscape for intelligence accountability in the UK and in the context of any future referendum on Scottish independence.

\section{Examining the proposed measures for intelligence accountability in an independent Scotland}

In evaluating the performance of the ISC, Peter Gill proposed six variables that are important in determining the effectiveness of any committee that oversees security intelligence: its form, mandate, membership, resources, access to information, and reporting. ${ }^{8}$ In Gill's model the form of an intelligence oversight committee depends upon the situation and status of the parent assembly. For example Gill makes the distinction between the committee traditions found in the US Congress and those in parliamentary systems, wherein the former offers the potential for independent action in terms of budgets, appointments and investigations, whilst in the latter, parliamentary committees are more likely to be the 'creatures of the executive'. ${ }^{9}$ Gill continues that the mandate - or terms of reference - for such a committee is likely to be a result of its form. Here Gill discusses the distinction between the relative freedom and independence of the US congressional model and the strictures of the UK statutory model. Considering a UK-style model he concludes that, to the extent that the executive is the dominant force in writing statutes, a committee's powers will reflect government preferences rather than those of an independent legislator. ${ }^{10}$ The selection of membership for any intelligence accountability committee is critical to its effectiveness and legitimacy. Gill considers that members' independence of the executive will be clearest if the members are chosen

\footnotetext{
$7 \quad$ Ibid., p. 261.

8 Gill (2007).

$9 \quad$ Ibid., p. 16.

10 Ibid.
} 
by the assembly itself, as in Argentina and Germany, rather than by the government, as was previously the case in the UK. ${ }^{11}$ Both informal, political selection processes and more formal eligibility, selection and vetting procedures will undoubtedly have an impact on the membership composition of an intelligence oversight committee. The inter-related issues of the extent of knowledge and depth of experience of members are also vital in assessing the measures for intelligence accountability. If accountability can be understood as the requirement for those in positions of power to provide answers to those whom they serve, then it is imperative that there is the requisite ability in an oversight committee to ask appropriate questions. Beyond an appropriately skilled and experienced membership, the issue of resources is also critical to the effectiveness of an intelligence oversight committee. Whilst Gill remarks upon the plethora of resources available to members in the US system, he also astutely recognises that 'generous resources do not guarantee effectiveness' if there is neither the will nor the skill to use them in the course of business. ${ }^{12}$ He continues that intelligence practitioners are highly skilled and can easily subvert the uninitiated outsider, and further contends that 'the first task for any committee is to discover what the right questions are. This, in turn, depends on the expertise, experience and energy of members and staff, if any, and the will to use them'. ${ }^{13}$ This leads to the fifth factor that Gill outlines in his model: access to information. Gill describes this as 'tokenistic' because, even where legislation formally enables unrestricted access, committees still need to use skill in negotiating with informal gatekeepers in the agencies under scrutiny. ${ }^{14}$ The final factor considered by Gill is reporting, particularly in the context of the tension between the secrecy of the data to which committee members will have access and the requirement to provide meaningful information on the activities of intelligence agencies to the parent assembly and the public. This leaves parliamentarians or committee members in the 'unenviable but inevitable position of being unable to tell their voters all that they know'.15

\begin{tabular}{ll}
\hline 11 & Ibid. \\
12 & Ibid., p. 17. \\
13 & Ibid. \\
14 & Ibid. \\
15 & Ibid., p. 18.
\end{tabular}




\section{Scotland and the Politics of Intelligence Accountability}

Colin Atkinson, Nick Brooke and Brian Harris

This chapter explores the politics of intelligence accountability in the context of the 2014 referendum on Scottish independence and the 2015 General Election in the UK. Drawing upon Peter Gill's model for assessing the effectiveness of security intelligence accountability, it argues that the Scottish Government's proposals for intelligence accountability in an independent Scotland indicated a vague and conservative intention to maintain similar mechanisms to the existing UK political settlement. By exploring the accountability mechanisms for security intelligence in other jurisdictions, this chapter suggests that shortcomings in the Scottish Government's proposals could have been addressed by learning lessons and adopting practices and processes from beyond the UK. The aftermath of the referendum - particularly the landslide victory in Scotland for the pro-independence SNP in the 2015 UK General Election - may herald consequences for both intelligence accountability in the UK and any future plan for accountability mechanisms in an independent Scotland. The previously unconsidered prospect of direct SNP representation on the UK Intelligence and Security Committee (ISC) - now a reality in the UK - raises the scenario that pro-independence politicians will develop the expertise, capital, and political legitimacy necessary for effective intelligence accountability that were lacking in the pre-referendum political landscape. 
In a democratic society, accountability is the requirement for those in positions of power to provide answers to those whom they serve. Accountability depends, therefore, upon either the presence of an informed, inquisitive, and engaged public or an array of elected representatives with similar qualities who act on the public's behalf. Although seemingly straightforward, accountability is not a simple administrative task; it poses a series of profound and fundamentally political challenges concerning the shape, composition, scope, power and limitations of any such regime. These challenges are compounded when one seeks to ensure accountability for the actions of intelligence and security agencies, organisations which, by their very nature, operate in conditions of secrecy. It has been argued that the problem here can be easily stated: 'how to provide for democratic control of a governmental function and institutions which are essential to the survival and flourishing of the state but which must operate to a certain extent in justifiable secrecy'. ${ }^{1}$ Ensuring the democratic accountability of intelligence services has been a persistent problem for western democracies, a challenge compounded by renewed concerns in the post-9/11 era that will undoubtedly persist in the years to come. ${ }^{2}$

In the UK there are various levels of intelligence accountability; however, the parliamentary Intelligence and Security Committee (ISC) is the principal mechanism that exists to provide for the accountability of the nation's intelligence agencies. ${ }^{3}$ Peter Gill has commented upon how the history of the oversight of security intelligence agencies in the UK is short, and how, with one or two exceptions, 'it simply did not exist before the 1970s, though its spread since then has been rapid'. ${ }^{4}$ The ISC was first established by the Intelligence Services Act 1994 to examine

1 I. Leigh, 'The Accountability of Security and Intelligence Agencies', in Handbook of Intelligence Studies, ed. by L. K. Johnson (Abingdon and New York: Routledge, 2007), pp. 67-81 (p. 67).

2 Hans Born and Ian Leigh, 'Democratic Accountability of Intelligence Services', in Armaments, Disarmament and International Security, ed. by Institute Stockholm International Peace Research (Oxford: Oxford University Press, 2007), pp. 193-214.

3 Mark Phythian, 'The British Experience with Intelligence Accountability', Intelligence and National Security, 22, 1 (2007), pp. 75-99; H. Bochel, A. Defty, and J. Kirkpatrick, Watching the Watchers: Parliament and the Intelligence Services (Basingstoke: Palgrave Macmillan, 2014).

4 Peter Gill, 'Evaluating Intelligence Oversight Committees: The UK Intelligence and Security Committee and the "War on Terror"', Intelligence and National Security, 22, 1 (2007), pp. 14-37 (p. 14). 
the policy, administration and expenditure of the Security Service, Secret Intelligence Service (SIS), and the Government Communications Headquarters (GCHQ). The Justice and Security Act 2013 reformed the ISC: making it a Committee of Parliament; providing greater powers; and increasing its remit to include oversight of operational activity and the wider intelligence and security activities of Government. Other than the three main intelligence and security agencies, the ISC examines the intelligence-related work of the Cabinet Office including: the Joint Intelligence Committee (JIC); the Assessments Staff; and the National Security Secretariat. The ISC also provides oversight of Defence Intelligence in the Ministry of Defence and the Office for Security and Counter-Terrorism (OSCT) in the Home Office. Members of the ISC are appointed by Parliament and the Committee reports directly to Parliament. The ISC may also make reports to the Prime Minister on matters which are sensitive in relation to national security. ${ }^{5}$

Intelligence oversight in the UK emerged and developed in the late twentieth and early twenty-first centuries; however, the effectiveness of the UK's accountability mechanisms have come increasingly into question. The responses to terrorist attacks on 9/11, the events that led to the Iraq War and the more recent series of disclosures from both Wikileaks and Edward Snowden revealed a range of controversial programs and activities undertaken by the intelligence agencies that were previously unknown to the public, media, and many politicians. It was against this backdrop - and in advance of the 2014 referendum on Scottish independence - that the Scottish Government decided upon the measures it would propose to ensure the accountability of a prospective security and intelligence agency for an independent Scotland. These measures were subsequently published in the White Paper on Scottish independence titled Scotland's Future: Your Guide to an Independent Scotland. ${ }^{6}$ This chapter evaluates the Scottish Government's proposal for intelligence accountability, locating it in comparative context by understanding the mechanisms that are in place in other

5 The Intelligence and Security Committee of Parliament, 'About the Committee' (2016), http://isc.independent.gov.uk/

6 Scottish Government, Scotland's Future: Your Guide to an Independent Scotland (Edinburgh: Scottish Government, 2013), http://www.gov.scot/resource/0043/0043 9021.pdf. 
similar jurisdictions. It argues that, despite the claim that a range of international comparators were studied, ${ }^{7}$ the Scottish Government's plans sought to replicate the existing UK model, without an appreciation of the challenges of such an approach. It concludes by exploring the political aftermath of the both the 2014 Scottish referendum and the 2015 UK General Election, with a particular focus upon the consequences of this new political landscape for intelligence accountability in the UK and in the context of any future referendum on Scottish independence.

\section{Examining the proposed measures for intelligence accountability in an independent Scotland}

In evaluating the performance of the ISC, Peter Gill proposed six variables that are important in determining the effectiveness of any committee that oversees security intelligence: its form, mandate, membership, resources, access to information, and reporting. ${ }^{8}$ In Gill's model the form of an intelligence oversight committee depends upon the situation and status of the parent assembly. For example Gill makes the distinction between the committee traditions found in the US Congress and those in parliamentary systems, wherein the former offers the potential for independent action in terms of budgets, appointments and investigations, whilst in the latter, parliamentary committees are more likely to be the 'creatures of the executive'. ${ }^{9}$ Gill continues that the mandate - or terms of reference - for such a committee is likely to be a result of its form. Here Gill discusses the distinction between the relative freedom and independence of the US congressional model and the strictures of the UK statutory model. Considering a UK-style model he concludes that, to the extent that the executive is the dominant force in writing statutes, a committee's powers will reflect government preferences rather than those of an independent legislator. ${ }^{10}$ The selection of membership for any intelligence accountability committee is critical to its effectiveness and legitimacy. Gill considers that members' independence of the executive will be clearest if the members are chosen

\footnotetext{
$7 \quad$ Ibid., p. 261.

8 Gill (2007).

$9 \quad$ Ibid., p. 16.

10 Ibid.
} 
by the assembly itself, as in Argentina and Germany, rather than by the government, as was previously the case in the UK. ${ }^{11}$ Both informal, political selection processes and more formal eligibility, selection and vetting procedures will undoubtedly have an impact on the membership composition of an intelligence oversight committee. The inter-related issues of the extent of knowledge and depth of experience of members are also vital in assessing the measures for intelligence accountability. If accountability can be understood as the requirement for those in positions of power to provide answers to those whom they serve, then it is imperative that there is the requisite ability in an oversight committee to ask appropriate questions. Beyond an appropriately skilled and experienced membership, the issue of resources is also critical to the effectiveness of an intelligence oversight committee. Whilst Gill remarks upon the plethora of resources available to members in the US system, he also astutely recognises that 'generous resources do not guarantee effectiveness' if there is neither the will nor the skill to use them in the course of business. ${ }^{12}$ He continues that intelligence practitioners are highly skilled and can easily subvert the uninitiated outsider, and further contends that 'the first task for any committee is to discover what the right questions are. This, in turn, depends on the expertise, experience and energy of members and staff, if any, and the will to use them'. ${ }^{13}$ This leads to the fifth factor that Gill outlines in his model: access to information. Gill describes this as 'tokenistic' because, even where legislation formally enables unrestricted access, committees still need to use skill in negotiating with informal gatekeepers in the agencies under scrutiny. ${ }^{14}$ The final factor considered by Gill is reporting, particularly in the context of the tension between the secrecy of the data to which committee members will have access and the requirement to provide meaningful information on the activities of intelligence agencies to the parent assembly and the public. This leaves parliamentarians or committee members in the 'unenviable but inevitable position of being unable to tell their voters all that they know'.15

\begin{tabular}{ll}
\hline 11 & Ibid. \\
12 & Ibid., p. 17. \\
13 & Ibid. \\
14 & Ibid. \\
15 & Ibid., p. 18.
\end{tabular}


Gill's sexpartite model - encompassing form, mandate, membership, resources, access to information, and reporting - offers a useful model to evaluate the effectiveness and performance of an intelligence accountability regime. In his own evaluative study Gill concluded that whilst the ISC had made some appropriate criticisms of the UK intelligence agencies the Committee can be faulted for the essentially managerialist nature of its reports and its failure to provide adequate attention to issues of public education and human rights. Gill's model for evaluation also provides a useful template to assess the measures proposed by the Scottish Government to provide intelligence accountability in the conditions of Scottish independence. The politics of intelligence in Scotland's independence referendum debate were 'hidden' in the sense that both public interest and political debate on this subject were quite limited in scope and intensity. ${ }^{16}$ The White Paper on independence outlined the Scottish Government's vision of threats to security in an independent Scotland and how this newlyindependent country would respond to such threats. It claimed that upon independence a single security and intelligence agency would be established with a requirement to work with partners to ensure Scotland's national security. The Scottish Government indicated that independence offered an opportunity to build a 'new model' for such work, which was fit for the twenty-first century and which provided a proportionate means of ensuring Scotland's national security. ${ }^{17}$ The establishment of a new security and intelligence agency would allow Scotland to 'do things differently, unconstrained by historical structures and precedent'. ${ }^{18}$ Crucially in this context the White Paper on independence also indicated the proposed measures for intelligence accountability in an independent $S$ cotland, through the role of legislation, governance and oversight of this new Scottish security and intelligence agency. Considering such matters the White Paper stated that:

16 Colin Atkinson, "“The Scottish MI5 Station Will Change to MI6. And You Know What MI6 Does!" Understanding the Hidden Politics of Intelligence in Scotland's Independence Referendum Debate', Scottish Journal of Criminal Justice Studies, 21 (2015), 5-24.

17 Scottish Government (2013), p. 261.

18 Ibid. 
The controls put in place will be wide-ranging and comprehensive. The planned legislation will bring democratic control of our national security to Scotland for the first time. Scottish Ministers will be accountable to the Scottish Parliament for what a Scottish security and intelligence agency does in their name. The Scottish Parliament and the Scottish equivalent of the relevant Commissioners will scrutinise and challenge the work of the agency, including its covert work. They will be given clear legislative powers to support their work, including the power to require documents to be provided and to require the senior management of the agency to give evidence. There will also be detailed budget scrutiny from the Auditor General for Scotland, and the top-level budget will be scrutinised by the Scottish Parliament as part of the Budget Bill. This scrutiny will ensure that the agency is acting properly, legally, efficiently and effectively, in line with international principles for intelligence service oversight. These processes must take transparency as their starting point. But in so doing, they will appropriately and rigorously protect aspects of the agency's work that cannot be made public, and will respect the control principle at all times. ${ }^{19}$

Given that there was no further discussion of intelligence accountability in the White Paper, this represents a useful point at which to apply Gill's six variables in order to determine the effectiveness of any proposed accountability structures and processes for a new Scottish security and intelligence service in an independent Scotland.

The form and mandate of the prospective regime for intelligence accountability in an independent Scotland was broadly sketched within the constraints of the White Paper, which outlined that'Scottish Ministers will be accountable to the Scottish Parliament for what a Scottish security and intelligence agency does in their name'. This would include the introduction of 'early legislation', written constitutional rights for Scottish citizens and clear arrangements for investigatory powers that build upon - and update where necessary — the existing UK legislation

19 Ibid., p. 266. The control principle, or rule, means that intelligence supplied by one party to another cannot be shared with an additional third-party without the originator's consent. See Stéphane Lefebvre, 'The Difficulties and Dilemmas of International Intelligence Cooperation', International Journal of Intelligence and Counter Intelligence, 16, 4 (2003), 527-42 (p. 532). Discussing the difficulties of this principle Robert David Steele reduced the rationale to a clear and parsimonious statement: the default condition of the secret intelligence world is 'do not share'. See R. D. Steele, 'Open Source Intelligence ', in Strategic Intelligence: Understanding the Hidden Side of Government, ed. by L. K. Johnson (Westport, CT and London: Praeger Security International, 2007), 95-122 (p. 113). 
governing such matters. ${ }^{20}$ Moreover, the White Paper detailed that the work of the Scottish security agency would be scrutinised and challenged by both the Scottish Parliament and 'the Scottish equivalent of the relevant Commissioners' - meaning the Intelligence Services Commissioner, the Interception of Communications Commissioner, and the Office of the Surveillance Commissioners under the pre-existing UK arrangement - using 'clear legislative powers' ${ }^{21}$ Beyond the bold claims of the White Paper there clearly remain significant unanswered questions in relation to the form, and subsequently the membership and resources, of such a regime for intelligence accountability. The ISC, for example, is a parliamentary committee comprised of nine members, drawn from both the House of Commons and the House of Lords, with none permitted to be a Minister of the Crown. These members, who are normally seasoned parliamentarians with relevant experience, are nominated by the Prime Minister but their appointment must be approved by parliament. The ISC Chair is selected by its members. It is possible to infer that an ISC equivalent for Scotland was not explicitly mentioned due to the controversial reputation of the ISC in relation to its provision of effective oversight, ${ }^{22}$ but there nevertheless remain unanswered questions relating to exactly who, in a prospective Scottish Parliament for an independent Scotland, would be responsible for the scrutiny and oversight of a Scottish security agency, and how they would be selected. Compounding these uncertainties, the issue of specific resources for intelligence accountability were not given any consideration in the White Paper. Resources were only discussed in the context of establishing the new security and intelligence agency itself, and not the accountability mechanisms for this service. In relation to an intelligence agency itself the Scottish Government proposed to maintain a 'comparable level of spending under independence' in relation to Scotland's pre-independence contribution, ${ }^{23}$ but this did not take into account any costs that would be associated with establishing the necessary resources to maintain effective oversight and accountability of this new security and intelligence agency. The most recent update

20 Scottish Government (2013), p. 266.

21 Ibid.

22 See Bochel, Defty, and Kirkpatrick (2014).

23 Scottish Government (2013), p. 266. 
from the ISC, following reforms made under the Justice and Security Act 2013, reported that it was supported by ten staff and an investigator, with a total budget of around $£ 1.3$ million per annum. ${ }^{24}$ There was no indication of the resources available to fund a Scottish mechanism for intelligence accountability.

Access to information and the ability to report such information effectively are vital components of any effective regime for intelligence accountability. The Scottish Government's White Paper was clear that both the Scottish Parliament and relevant commissioners would be given clear legislative powers to support their work, including the powers to require the provision of documents from a Scottish security agency and to require the agency's senior management to give evidence. ${ }^{25}$ There was no real clarity in Scotland's Future on the ways in which such information would be reported, beyond taking transparency as 'a starting-point' whilst respecting both the need to protect the agency's work where necessary and the control principle. In broadly resonating with the UK legislation and arrangements - and particularly the Justice and Security Act 2013, which reformed and emboldened the ISC - these commitments ultimately appear as a case of plus ça change, plus c'est la même chose, a feature that inhabits (or inhibits) much of the thinking on issues of intelligence and security in the Scottish Government's White Paper. The political strategy of such an approach is expedient and understandable: gain public confidence through political reassurance. It is worth recalling here, however, that Gill warned against the 'tokenism' of legislation, highlighting the requirement for the use of skill in negotiating with informal gatekeepers in the agencies under scrutiny. ${ }^{26}$ In this context the immaturity of Scotland's political structures in dealing with matters of national security must be considered.

Scotland's Future was explicit in stating that the planned legislation would bring democratic control of national security to Scotland for the first time. A case can certainly be constructed that the existing cadre of 129 elected members in the Scottish Parliament broadly lacks the

24 Intelligence and Security Committee of Parliament, Intelligence and Security Committee of Parliament Annual Report 2015-2016 (London: HMSO, 2016), https://b1cba9 b3-a-5e6631fd-s-sites.googlegroups.com/a/independent.gov.uk/isc/files/20152016_ISC_AR.pdf

25 Intelligence and Security Committee of Parliament (2016).

26 Gill (2007), p. 17. 
capacity and capability to effectively scrutinise an emerging intelligence and security agency with the same rigour as that of its Westminster counterpart. It is true to say that an intelligence oversight committee in Scotland would have less ground to cover, at least in the longer-term, and would thus require fewer political representatives to function effectively. However, it is unclear as to whether, based on the existing arrangements, there would actually be enough MSPs with the skills, knowledge and experience to provide the necessary level of scrutiny, particularly given the expanded remit of a newly independent Scottish Parliament to provide governance of, and accountability for, whole new swathes of political activity. The provision of additional civil service support would also be necessary, but at least here a case can be made, cost permitting, for the 'poaching' of expertise from the existing UK structures. In considering the Scottish Government's proposal for intelligence accountability a key question thus emerges: would an independent Scotland have the right people asking the right questions, as well as the necessary resources, to hold a developing intelligence and security agency to account effectively? The answer to this question may be informed by a considered analysis of the successes and failures of intelligence oversight and accountability in other European nations that are comparatively similar to Scotland.

\section{Comparison with accountability mechanisms in other jurisdictions}

The French security expert Philippe Hayez recently remarked that intelligence and security services have moved from serving princes to serving citizens. ${ }^{27}$ Not only do contemporary democratic societies now require their intelligence agencies to be accountable, but the bodies responsible for this task are often overseeing secretive agencies that have been established for a considerable period of time. The White Paper, Scotland's Future, argues that this is to Scotland's benefit, allowing Scotland to proceed unburdened by the past; however, as previously argued in this chapter, there are real challenges with regards

27 P. Hayez, 'National Oversight of International Intelligence Cooperation', in International Intelligence Cooperation and Accountability, ed. by H. Born, I. Leigh, and A. Wills (Abingdon and New York: Taylor \& Francis, 2011), pp. 151-69 (p. 151). 
to the extent to which the Scottish Parliament would have the capacity and capability to carry out this task. Nevertheless, in comparing an independent Scotland to other similar nations it is clear that Scotland is in a unique position to establish, at the same time, both a new security agency and mechanisms for the oversight of such an agency.

The unique position of Scotland in relation to the simultaneous design and implementation of both an intelligence service and an accountability mechanism is further compounded when one considers the post-'shock' modification of intelligence oversight. Writing on intelligence oversight in the US in the Handbook of Intelligence Studies, Loch K. Johnson noted,

An analysis of intelligence accountability indicates a pattern in recent decades: a major intelligence scandal or failure - a shock - converts perfunctory patrolling into a burst of intense firefighting, which is the followed by a period of dedicated patrolling that yields remedial legislation or other reforms designed to curb inappropriate activities in the future. [...] Once the firestorm has subsided and reforms are in place, however, lawmakers return to a state of relative inattention to intelligence issues..$^{28}$

Johnson's argument, one that has played out frequently in the post9/11 security landscape, is that the greatest impetus for the progress of oversight is an intelligence failure or scandal that leads to public demand for change. Terrorist attacks by groups linked to Al Qaeda in Madrid and London, the massacre committed by Anders Behring Breivik in Norway, and the killing of Theo van Gogh in the Netherlands all prompted inquiries about intelligence failures. Such inquiries, which fall under the purview of security oversight, were carried out by existing or speciallyconvened bodies, and from which changes were assumed to follow. Similarly, the intelligence scandals surrounding the recourse to the 2003 Iraq War, the treatment of prisoners in Abu Ghraib, and the revelations from whistle blowers such as Wikileaks and Edward Snowden, have all had a similar impact: leading to inquiries that can be considered within the remit of oversight and intelligence accountability. It is from the shock of intelligence failures and scandals that progress on intelligence

28 L. K. Johnson, 'A Shock Theory of Congressional Accountability for Intelligence', in Handbook of Intelligence Studies, ed. by L. K. Johnson (Abingdon and New York: Taylor \& Francis, 2007), pp. 343-60 (p. 344). 
and security oversight is frequently made, thus raising the possibility that the measures for intelligence accountability in Scotland may not be fully effective until a similar shock is experienced. Nevertheless, the effectiveness of intelligence oversight and accountability mechanisms can be evaluated and further developed by considering the process in similar nations.

As highlighted earlier in this chapter, Scotland's Future indicated that an independent Scotland would draw from the UK model of security intelligence oversight, with little indication that any such model would be tailored to fit the challenges of the Scottish context. An independent Scotland would have a more limited global reach, presence, and footprint than that of the UK, with the possible implication that Scotland would face a decreased threat from international terrorism, as well as other security risks. This could be termed the 'small nation security dividend'. This section will consider approaches to intelligence oversight and accountability in two states closer in size and global presence to Scotland: Norway and Belgium..$^{29}$ The appropriate mechanisms in these two nations will be examined to identify the viability of alternative approaches beyond the replication of the UK model in the context of an independent Scotland.

\section{Norway}

Writing about intelligence oversight in Norway before the attacks committed by Anders Behring Breivik, Fredrik Sejersted argued, 'the preconditions for making intelligence accountable are among the most favourable in the world. If democratic oversight is not possible [in Norway], it is not possible anywhere' ${ }^{30}$ The Norwegian model focuses on legislative oversight, with accountability directly falling to the Parliamentary Oversight Committee on Intelligence and the Security Services (known as the EOS Committee). The EOS Committee was

29 Ireland, a country with historical, cultural and societal similarities to Scotland, was also considered for comparison, but the absence of a dedicated security agency raises several challenges in relation to a comparative study of intelligence oversight regimes.

30 F. Sejersted, 'Intelligence and Accountability in a State without Enemies: The Case of Norway', in Who's Watching the Spies?: Establishing Intelligence Service Accountability, ed. by H. Born, L. K. Johnson, and I. Leigh (Washington DC: Potomac Books, 2005), pp. 119-41 (p. 120). 
established in the 1990s based on the recommendations of the Lund Commission, established to consider accusations of illegal surveillance by the security services. This Committee is appointed by and reports directly to Parliament, containing seven non-parliamentary members: an aspect that differs from oversight models in other Western states that draw their personnel from parliamentarians. The Committee operates with a high level of independence from political interference, and conducts oversight in two ways: 'through inspections of the agencies, and by dealing with complaints and inquiries' ${ }^{31}$ Returning to the six key variables outlined by Gill, Norway's accountability mechanisms meet these criteria fully with regards to membership, form and mandate. In addition to the work of the committee, the executive retains control over traditional elements of the oversight infrastructure through traditional governmental administrative structures. The main purpose of the Committee's work is safeguarding individuals against abuses committed by the security agencies (focusing on the protection of civil liberties and restricting intrusive surveillance methods), but it largely refrains from evaluating and analysing the efforts of the security agencies, with this task falling to the executive branch.

In the wake of the terrorist attacks committed by Anders Behring Breivik in July 2011, a ten-person special commission headed by Alexandra Bech Gjørv was established to ascertain the facts behind the attacks and make recommendations to help prevent similar attacks in the future. Their report, delivered in August 2012, indicated that the police could have done more to prevent the bombings and criticised the response to reports of shootings on Utøya, especially the time it took to reach the island itself. ${ }^{32}$ The Gjørv report could be considered an extraordinary act of security oversight, coming in the wake of a shock. Norway, so often portrayed by many as a nation from which Scotland would do well to learn lessons, introduced oversight measures in the direct wake of an intelligence scandal in the mid-1990s, and the Breivik attacks on 2011. In line with the social democratic values often associated with Scandinavian states, Norway has chosen to isolate its oversight infrastructure from direct political control by granting the principal

31 Sejersted (2005), p. 128.

32 [N.a.], 'Norway Police "Could Have Stopped Breivik Sooner"', BBC News, 13 August 2012, http://www.bbc.co.uk/news/world-europe-19241327 
committee substantial independence, whilst retaining executive control of the security services. Moreover, the committee's focus on preventing abuses of Norwegian citizens by the security agencies is logical considering the reduced threat of international terrorism faced by Norway.

\section{Belgium}

Belgium, is a smaller country geographically than Scotland but twice as populous, with nearly eleven million citizens. Like Scotland, it borders a much larger country that has been directly attacked by actors linked to international terrorist groups in the last decade. Similar to Norway, the Belgian intelligence and security oversight body (the Standing Intelligence Agencies Review Committee, or Committee I) was set up in the 1990s and maintains a public presence. The Committee consists of three individuals, one of whom acts as chairman, a position that must be held by a magistrate. ${ }^{33}$ The Belgium Senate appoints these individuals, as well as two substitute members on a six-year term. The principal role of the Committee is described as 'reviewing the activities and functioning of State Security and the General Intelligence and Security Service [...] [and] the functioning of the Coordination Unit for Threat Assessment and the various services that support this coordination unit', focusing on the 'legitimacy (review of observance of the applicable laws and regulations), effectiveness (supervision of the efficiency of the intelligence services), and coordination (the mutual harmonization of the work of the services concerned)' of these bodies. ${ }^{34}$

Broadly similar to Norway and Scotland in international profile, Belgium demonstrates the limits of reliance on the 'small nation security dividend', as the events of 22 March 2016 demonstrated, when thirtytwo people were killed by three bombings in the capital, Brussels: the first two at the city's airport, the latter on the Metro. This attack came only months after the November 2015 Paris attack, carried out by a Belgian-based group of Islamic State supporters, of whom some were

33 [N.a.], 'A Review Committee Acting as an Jurisdictional Body. The New Role of the Belgian Committee within the Framework of Reviewing Special Intelligence Methods', in Workshop on Best Practices for Intelligence and Intelligence Oversight, Montreux, 1-2 March 2010.

Ibid. 
Belgian-born. ${ }^{35}$ Previous to this, Belgium has witnessed the threat from its own citizens returning from the conflicts in Syria and Iraq in a deadly attack on a Jewish Museum in Brussels in June 2014 and the killing of two 'suspected jihadists' who had been suspected by police of an imminent attack in January 2015. ${ }^{36}$ This rapid series of events has led to suggestions that Belgian intelligence is 'regarded as weak [...] more divided than most and more beset with scandals and charges of inefficiency' ${ }^{37}$ In response to these attacks, and to questions about the ability of the Belgian intelligence services, the president of Committee I, Guy Rapaille, pushed back, stating, 'these attacks show that more coordination with the United States is clearly desirable [...] but you have to remember that big powers guard their intelligence very closely' ${ }^{38}$ Furthermore, another member of the oversight committee publicly suggested, 'we are paying for our naïveté [...] it's not a weakness in intelligence. It's a weakness in society'. ${ }^{39}$ Thus, in a short space of time Belgium has gained experience in the necessity of responding to the threat of international terrorism and it seems likely that Committee I will have a substantial role to play in investigating the extent to which the intelligence agencies failed, and how these inadequacies can be addressed.

The most visible component of Committee I is its Investigation Service, which can carry out investigations based on 'its own initiative, on the request of the Senate, the Chamber of Representatives or the competent minister or authority, ${ }^{40}$ or on the request of a citizen or a

35 [N.a.], 'Paris and Brussels Bombers' Links Uncovered', BBC News, 9 April 2016, http://www.bbc.co.uk/news/world-europe-35879401

36 [N.a.], 'Belgian Anti-Terror Raid in Verviers Leaves Two Dead', BBC News, 16 January 2015, http://www.bbc.co.uk/news/world-europe-30840160

37 John Lloyd, 'The World's Spies Agree Belgian Intelligence Is Broken', Reuters, 24 March 2016, http://blogs.reuters.com/great-debate/2016/03/24/how-the-worldsintelligence-services-rate-each-other/

38 Mark Hosenball, 'U.S. Frustration Simmers over Belgium's Struggle with Militant Threat', Reuters, 24 March 2016, http://www.reuters.com/article/usbelgium-blast-usa-intelligence-idUSKCNOWQ0BU

39 Adam Nossiter, 'Brussels Attacks Underscore Vulnerability of an Open European Society', The New York Times, 25 March 2016, http://www.nytimes.com/2016/03/23/ world/europe/belgium-security.html

40 When asked to carry out an investigation by Parliament or by Ministers of Justice, Defence or the Interior, Committee I is required to carry out the investigation. Standing Intelligence Agencies Review Committee, 'Home' (2016), http://www. comiteri.be/index.php/en/. See Peter De Smet, 'Excerpt of the Speech Held at the 6th International Intelligence Review Agencies Conference ('Does Setting Priorities Mean "to Lose"?')', in 6th International Intelligence Review Agencies Conference (New Zealand, 2008). 
civil servant who lodges a complaint or files a denunciation' or 'in the framework of a parliamentary enquiry' ${ }^{41}$ The Committee is a powerful body: it can compel the security services to provide all documents relating to an investigation that it chooses to undertake, and because all members and employees of the committee hold security clearance, they can request classified material. Furthermore, the Committee has the power to 'advise' the Belgian courts on the legality of 'special and exceptional methods' and 'forbid the further use of the method in question' if deemed illegal. ${ }^{42}$ Additionally, the Committee can summon anyone to undertake an interview and may require the individual to testify under oath, as well as having strong reporting capacities. Committee I is extraordinarily powerful when it comes to requesting information and testimony. Thus, there are many similarities between these two cases: operating independently from parliament with strong investigative powers.

\section{Reflections on the Scottish case}

Scotland has, in different ways, much in common with the two countries considered here. Whilst it is tempting to rely on the smallnation dividend when considering the security implications for an independent Scotland the series of terrorist attacks conducted, or planned, in Belgium between 2014 and 2016, and the attacks of Anders Breivik in Norway, caution against complacency, particularly if an independent Scotland sought to remain a close ally of both the UK and the US. With particular regards to intelligence accountability, Scotland could benefit from considering the examples of Norway and Belgium in the appointment of non-parliamentary experts to the oversight committees. This would alleviate the problem that results from the lack of experience, expertise and skill in overseeing the functions of the intelligence security services among the vast majority of the existing cadre of Scottish parliamentarians. Furthermore, these cases demonstrate some of the advantages of legislative independence of the primary security and intelligence oversight bodies, and Scotland would be well served if a similar model were adopted. Yet when it comes to 
security oversight there is no model that Scotland should adopt in its entirety, and the requirement would remain to structure a security and intelligence service and accountability mechanisms to meet the challenges faced by an independent Scotland.

\section{Post-referendum politics and intelligence accountability}

The 2014 Scottish referendum on independence and the 2015 UK General Election remain fresh in the collective political consciousness, not least given the decision of the UK electorate in June 2016 to leave the European Union. Considered and dispassionate analysis of post-referenda politics has therefore been limited in volume, breadth and rigour. It is clear that, whilst Scotland voted to remain part of the UK, the electoral landscape of both Scottish and UK politics was transformed by the landslide victory for the pro-independence SNP in the 2015 UK General Election, which returned 56 Scottish representatives to Westminster from a possible total of 59. Whilst there is some scholarship and commentary on the most prominent issues affecting this post-referendum political landscape - from tax powers ${ }^{43}$ to Trident ${ }^{44}$ - the impact of the Scottish referendum White Paper, debate, result and subsequent electoral outcomes on the accountability of the intelligence agencies in the UK has attracted little to no attention. The nature of this now transformed post-referendum politics, however, may possibly herald some important consequences for both intelligence accountability in the UK and any future plan for accountability mechanisms in an independent Scotland.

The most immediate outcome for intelligence accountability in postreferendum politics in the UK was apparent in the third variable in Gill's sexpartite model: the change in membership of the Intelligence and Security Committee. The dissolution of parliament in advance of the 2015 General Election necessitated the parallel dissolution of the ISC. Previous ISC members ceased to be so. Similarly, the election of a new government required that a new ISC membership be established.

43 J. Aitken, 'The Continuing Battle for Scottish Tax Powers', in After Independence: The State of the Scottish Nation Debate, ed. by G. Hassan and J. Mitchell (Edinburgh: Luath Press Ltd, 2013).

44 W. Walker, 'Trident's Insecure Anchorage', in Hassan and Mitchell (2013). 
Following the electoral success of the SNP there emerged some support for the inclusion of an SNP member on this new ISC, with initial reports suggesting that Scotland's former First Minister, Alex Salmond, would be the front-runner for such a post. ${ }^{45}$ The inclusion of SNP representation on the ISC, whoever the member would be, received a mixed response from some quarters. For example, a small number of Unionist MPs voiced concern over the SNP stance on key issues of defence and security, whilst others accepted the requirement for SNP representation on the ISC as part of the democratic process. ${ }^{46}$ Following the 2015 General Election the SNP was given representation on the ISC: on 9 September 2015 the Rt Hon Angus Robertson MP was nominated to this committee and subsequently appointed by the Prime Minister. The appointment of Robertson, the parliamentary group leader of the SNP at Westminster, is notable not only for his support for independence and his opposition to the UK nuclear deterrent capability, but also for his views on the role and remit of the ISC. Robertson has been, for example, critical of the UK Government in relation to parliamentary oversight of UK drone strikes in Syria. ${ }^{47}$ The impact of the change in ISC membership may, however, extend beyond a shift in the nature of intelligence accountability in the UK context; the inclusion of SNP representation on the ISC may also provide valuable experience, capital, and political legitimacy that could deepen and enhance any future plans for intelligence accountability in an independent Scotland.

The 2014 referendum on Scottish independence was undertaken on the shared proviso that it would be a 'once in a generation' event; ${ }^{48}$

45 See 'Salmond Lined up for Role as Top Spy Chief', Sunday Post, 10 May 2015, https:// www.sundaypost.com/news/scottish-news/salmond-lined-up-for-role-as-top-spychief/ This speculation was seemingly predicated on two factors. Firstly, that ISC members are by convention also Privy Councillors, and Alex Salmond was then the only Privy Councillor in the SNP's ranks. Secondly, that Salmond had ruled himself out of other important roles at Westminster.

46 Michael Settle, 'Tory Fears over Allowing SNP Role in UK Security', Herald, 22 May 2015, http://www.heraldscotland.com/news/13214836.Tory_fears_over_ allowing_SNP_role_in_UK_security/

47 House of Commons, House of Commons Hansard Debates for 09 Sep 2015 (Pt 0001) (London: HMSO, 2015), http://www.publications.parliament.uk/pa/cm201516/ cmhansrd/cm150909/debtext/150909-0001.htm\#15090926000005

48 Karen McVeigh, 'Scottish Referendum: Yes and No Agree It's a Once-in-a-Lifetime Vote', Guardian, 17 September 2014, https://www.theguardian.com/politics/2014/ 
however, the issue of a second referendum has remained very much in the political spotlight. ${ }^{49}$ As previously argued in this chapter, the mechanism for intelligence accountability sketched in Scotland's Future offered little deviation from the existing UK model. In the context of a future referendum on Scottish independence, however, one of the most significant political consequences of the revised membership of the ISC may be the experience and, more importantly, political legitimacy, gained through SNP representation on the ISC, and the associated capital and credibility that would be accrued as a result. As Bochel, Defty, and Kirkpatrick noted in Watching the Watchers,

Like the departmental select committees, the ISC has allowed a small number of parliamentarians to acquire specialist knowledge in a particular policy area, and moreover one in which few parliamentarians have had any prior experience. ${ }^{50}$

Nevertheless, there will remain challenges for a prospective intelligence accountability mechanism in Scotland, particularly given that the ISC has, to a great extent, relied upon the experience of its members from both chambers of the UK parliament. ${ }^{51}$ The nature of the now transformed post-referenda political landscape in the UK - where Nationalist representation at Westminster is stronger than ever before and the prospect of a second referendum on Scottish independence remains a clear possibility - may result in some significant changes in the practices of intelligence accountability in the UK and the rigour of any proposed mechanisms for intelligence accountability in an independent Scotland.

sep/17/scottish-independence-referendum-yes-no-agree-once-in-lifetime-vote; Keely Lockhart, 'Alex Salmond: "This Is a Once in a Generation Opportunity for Scotland"', Telegraph, 14 September 2014, http://www.telegraph.co.uk/news/ uknews/scottish-independence/11095210/Alex-Salmond-This-is-a-once-in-ageneration-opportunity-for-Scotland.html

49 [N.a.], 'Nicola Sturgeon Asks Opponents to Back Second Independence Referendum', BBC News, 24 September 2015, http://www.bbc.co.uk/news/ uk-scotland-scotland-politics-34333394; Jon Stone, 'Second Scottish Independence Referendum Is Inevitable, Says Nicola Sturgeon', Independent, 12 October 2015, http://www.independent.co.uk/news/uk/politics/another-scottish-independencereferendum-is-inevitable-says-nicola-sturgeon-a6690586.html

50 Bochel, Defty, and Kirkpatrick (2014), p. 77.

51 Ibid., p. 79. 


\section{Conclusion}

This chapter has explored the politics of intelligence accountability in the context of the 2014 referendum on Scottish independence and the 2015 General Election. It examined and evaluated the Scottish Government's vision for the accountability of a proposed new security and intelligence service in Scotland, exploring the consequences of the decision to remain in the UK and the 2015 electoral outcome on both intelligence accountability mechanisms in the UK and for a future independent Scotland. Drawing upon Gill's model for assessing the effectiveness of security intelligence accountability, the chapter argued that the Scottish Government's proposals for accountability mechanisms were vague, but inherently conservative, indicating a continuation of similar mechanisms used in the existing UK political settlement. This issue was brought into particular focus by exploring the accountability mechanisms for security intelligence in other jurisdictions, a process that highlights how shortcomings in the Scottish Government's proposals could have been addressed by learning lessons and adopting practices and processes from beyond the UK. Despite Scotland's decision to remain part of the UK, the aftermath of the referendum, particularly the landslide victory in Scotland for the pro-independence SNP in the 2015 UK General Election, may herald some important consequences for both intelligence accountability in the UK and any future plan for accountability mechanisms in an independent Scotland. The previously unconsidered prospect of direct SNP representation on the ISC - now a reality in the UK - raises the issue that pro-independence politicians will develop the expertise, capital, and political legitimacy necessary for effective intelligence accountability that were lacking in the prereferendum political landscape. 


\section{References}

[N.a.], 'A Review Committee Acting as an Jurisdictional Body. The New Role of the Belgian Committee within the Framework of Reviewing Special Intelligence Methods', paper presented at 'Workshop on Best Practices for Intelligence and Intelligence Oversight', Montreux, 1-2 March 2010.

—, 'Norway Police “Could Have Stopped Breivik Sooner"', BBC News, 13 August 2012, http://www.bbc.co.uk/news/world-europe-19241327

-, 'Belgian Anti-Terror Raid in Verviers Leaves Two Dead', BBC News, 16 January 2015, http://www.bbc.co.uk/news/world-europe-30840160

—, 'Nicola Sturgeon Asks Opponents to Back Second Independence Referendum', BBC News, 24 September 2015, http://www.bbc.co.uk/news/uk-scotlandscotland-politics-34333394

-, 'Paris and Brussels Bombers' Links Uncovered', BBC News, 9 April 2016, http://www.bbc.co.uk/news/world-europe-35879401

Aitken, J., 'The Continuing Battle for Scottish Tax Powers', in After Independence: The State of the Scottish Nation Debate, ed. by G. Hassan and J. Mitchell (Edinburgh: Luath Press Ltd, 2013).

Atkinson, Colin, "“The Scottish MI5 Station Will Change to MI6. And You Know What MI6 Does!" Understanding the Hidden Politics of Intelligence in Scotland's Independence Referendum Debate', Scottish Journal of Criminal Justice Studies, 21 (2015), 5-24.

Bochel, H., Defty, A., and Kirkpatrick, J., Watching the Watchers: Parliament and the Intelligence Services (Basingstoke: Palgrave Macmillan, 2014).

—, " New Mechanisms of Independent Accountability”: Select Committees and Parliamentary Scrutiny of the Intelligence Services', Parliamentary Affairs, 68 (2015), 314-31, http://dx.doi.org/10.1093/pa/gst032

Born, Hans and Leigh, Ian, 'Democratic Accountability of Intelligence Services', in Armaments, Disarmament and International Security, ed. by Stockholm International Peace Research Institute (Oxford: Oxford University Press, 2007), pp. 193-214.

De Smet, Peter, 'Excerpt of the Speech Held at the 6th International Intelligence Review Agencies Conference ('Does Setting Priorities Mean “to Lose”?')', in 6th International Intelligence Review Agencies Conference (New Zealand, 2008).

Gill, Peter, 'Evaluating Intelligence Oversight Committees: The UK Intelligence and Security Committee and the "War on Terror"', Intelligence and National Security, 22 (2007), 14-37, http://dx.doi.org/10.1080/02684520701200756 
Hayez, P., 'National Oversight of International Intelligence Cooperation', in International Intelligence Cooperation and Accountability, ed. by H. Born, I. Leigh, and A. Wills (Abingdon and New York: Taylor \& Francis, 2011), pp. 151-69.

Hosenball, Mark, 'U.S. Frustration Simmers over Belgium's Struggle with Militant Threat', Reuters, 24 March 2016, http://www.reuters.com/article/usbelgium-blast-usa-intelligence-idUSKCNOWQ0BU

House of Commons, House of Commons Hansard Debates for 09 Sep 2015 (Pt 0001) (London: HMSO, 2015), http://www.publications.parliament.uk/pa/ cm201516/cmhansrd/cm150909/debtext/150909-0001.htm\#15090926000005

Intelligence and Security Committee of Parliament, Intelligence and Security Committee of Parliament Annual Report 2015-2016 (London: HMSO, 2016), https://b1cba9b3-a-5e6631fd-s-sites.googlegroups.com/a/independent.gov. uk/isc/files/2015-2016_ISC_AR.pdf

—, 'About the Committee' (2016), http://isc.independent.gov.uk/

Johnson, L. K., 'A Shock Theory of Congressional Accountability for Intelligence', in Handbook of Intelligence Studies, ed. by L. K. Johnson (Abingdon and New York: Taylor \& Francis, 2007), pp. 343-60.

Lefebvre, Stéphane, 'The Difficulties and Dilemmas of International Intelligence Cooperation', International Journal of Intelligence and CounterIntelligence, 16 (2003), 527-42, http://dx.doi.org/10.1080/716100467

Leigh, I., 'The Accountability of Security and Intelligence Agencies', in Handbook of Intelligence Studies, ed. by L. K. Johnson (Abingdon and New York: Routledge, 2007), pp. 67-81.

Lloyd, John, 'The World's Spies Agree Belgian Intelligence Is Broken', Reuters, 24 March 2016, http://blogs.reuters.com/great-debate/2016/03/24/how-theworlds-intelligence-services-rate-each-other/

Lockhart, Keely, 'Alex Salmond: “This Is a Once in a Generation Opportunity for Scotland"', Telegraph, 14 September 2014, http://www.telegraph.co.uk/ news/uknews/scottish-independence/11095210/Alex-Salmond-This-is-aonce-in-a-generation-opportunity-for-Scotland.html

McVeigh, Karen, 'Scottish Referendum: Yes and No Agree It's a Once-in-aLifetime Vote', Guardian, 17 September 2014, https://www.theguardian.com/ politics/2014/sep/17/scottish-independence-referendum-yes-no-agree-oncein-lifetime-vote

Nossiter, Adam, 'Brussels Attacks Underscore Vulnerability of an Open European Society', The New York Times, 25 March 2016, http://www.nytimes. com/2016/03/23/world/europe/belgium-security.html 
Phythian, Mark, 'The British Experience with Intelligence Accountability', Intelligence and National Security, 22 (2007), 75-99, http://dx.doi.org/10.10 $80 / 02684520701200822$

Picken, A., 'Salmond Lined up for Role as Top Spy Chief', Sunday Post, 10 May 2015, https://www.sundaypost.com/news/scottish-news/salmond-lined-upfor-role-as-top-spy-chief/

Scottish Government, Scotland's Future: Your Guide to an Independent Scotland (Edinburgh: Scottish Government, 2013), http://www.gov.scot/ resource/0043/00439021.pdf

Sejersted, F., 'Intelligence and Accountability in a State without Enemies: The Case of Norway', in Who's Watching the Spies?: Establishing Intelligence Service Accountability, ed. by H. Born, L. K. Johnson and I. Leigh (Washington DC: Potomac Books, 2005), pp. 119-41.

Settle, Michael, 'Tory Fears over Allowing SNP Role in UK Security', Herald, 22 May 2015, http://www.heraldscotland.com/news/13214836.Tory_fears_ over_allowing_SNP_role_in_UK_security/

Standing Intelligence Agencies Review Committee, 'Home' (2016), http://www. comiteri.be/index.php/en/

Steele, R. D., 'Open Source Intelligence ', in Strategic Intelligence: Understanding the Hidden Side of Government, ed. by L. K. Johnson (Westport, CT and London: Praeger Security International, 2007), pp. 95-122.

Stone, Jon, 'Second Scottish Independence Referendum Is Inevitable, Says Nicola Sturgeon', Independent, 12 October 2015, http://www.independent. co.uk/news/uk/politics/another-scottish-independence-referendum-isinevitable-says-nicola-sturgeon-a6690586.html

Walker, W., 'Trident's Insecure Anchorage', in After Independence: The State of the Scottish Nation Debate, ed. by G. Hassan and J. Mitchell (Edinburgh: Luath Press Ltd, 2013). 
